\title{
Enhancing Students' Biology-Critical Thinking Skill through CIRC-Based Scientific Approach (Cirsa)
}

\author{
Rizhal Hendi Ristanto*, Refirman Djamahar, Erna Heryanti, Ilmi Zajuli Ichsan \\ Department of Biology Education, Faculty of Mathematics and Natural Science, Universitas Negeri Jakarta, Indonesia
}

Received September 7, 2019; Revised January 27, 2020; Accepted March 24, 2020

Copyright $\odot 2020$ by authors, all rights reserved. Authors agree that this article remains permanently open access under the terms of the Creative Commons Attribution License 4.0 International License.

\begin{abstract}
Critical thinking skills are referred to as one of the 21st-century skills. These skills should be empowered through Biology learning. This study aims to analyze the improvement of biology-critical thinking skills in students who are taught through the CIRC learning model based on the scientific approach (Cirsa). Critical thinking skills are measured by tests developed by researchers and validated by theoretical biologists. The instrument includes indicators of critical thinking skills such as formulating problems, giving arguments, making deductions, conducting inductions, conducting evaluations, and deciding and implementing. This study used a quasi-experimental method with a pretest-posttest non-equivalent control group design. This study involved 160 students $(\mathrm{M}=95, \mathrm{~F}=65)$ of 8th grade of a Madrasah Tsanawiyah School in Bogor. The findings of this study show that students who are taught by Cirsa have higher Biology-critical thinking skills than those by conventional learning. In conclusion, Cirsa learning was recommended to develop or enhance students' critical thinking skills related to biological concepts.
\end{abstract}

Keywords Biology, Circ, Cirsa, Critical Thinking, Scientific Approach

\section{Introduction}

Biology education, especially in anatomy and physiology learning, is essential in developing scientific knowledge among students [1,2]. Anatomy and physiology are knowledge related to constituent organs and their function for an organism, including the work mechanism process $[3,4]$. Excretion and respiratory system learned at secondary school level refers to human physiology science $[3,5,6]$. The 2013 Curriculum applied in Indonesia includes topics on constituent organs and their functions, work mechanism, and disruptions occurred in an organism
[7-10].

Studying biology should not merely focus on knowledge related to the curriculum components. However, it should be able to empower a variety of thinking skills required by learners [11,12]. As human beings living in the 21st century, learners must be equipped with four skills, namely collaboration, communication, creative thinking, and critical thinking [7,13-15]. The research focuses on critical thinking skill empowerment. Various studies that empower critical thinking skills in Biology learning include [12,16-19]. It is proof that critical thinking skills are empowered through Biology learning.

Students with excellent critical thinking skills are more sensitive to social, scientific, and practical problems [20,21]. Critical thinking could also assist in determining careful assessment in decision making and solving daily-life biology problems [19,22]. Critical thinking implementation in Biology learning provides an opportunity to develop analytic, inductive, and deductive thinking skills to solve fundamental event-related problems [21,23].

Students with good critical thinking skills in a learning environment could provide favorable implications in terms of cultivating an attitude of self-confidence by considering self as a person who can give benefits by becoming an active contributor in the learning process [24,25]. Critical thinking skills in Biology learning could be developed through cooperative learning [16,26] emphasizing on reading activities [7,21] and scientific approach-oriented activities [20,23,27]. Scientific approach gives opportunity to students to discuss with others to make analysis of the natural phenomena and try to evaluate and solve problem, so this can improve critical thinking $[13,14]$.

The scientific approach is recommended in the 2013 Curriculum in Indonesia [7,28,29]. Indonesian educational process standard states that learning is conducted by selecting a scientific approach adjusted to competence characteristics and level of education. Several activities in the scientific approach include observing, asking, trying, 
reasoning, and communicating [7,30].

The obstacle in Biology learning in the 2013 Curriculum is that not all learning models accommodate those activities. A scientific approach-based Cooperative Integrated Reading and Composition (CIRC) or known as Cirsa has been developed [7]. Research results indicate that Cirsa learning has been stated as valid and effective to be applied in Biology learning and has potential to empower 21 st-century skills $[7,8]$.

Cirsa, as one of cooperative learning manifestation, is believed to be capable of empowering students to participate in learning process [31,32] actively. The activity could be skills in decision making, evaluating, and commenting to one another so as it could enhance critical thinking skills [33-35]. CIRC is a student-centered learning design focusing on critical study assignments on reading and presenting the result through class presentation $[31,32]$. The learning has proven to be able to improve critical thinking skills on motions in plants [36].

Many other studies on critical thinking skills have been conducted, for example, on students' critical thinking ability profiles [37-39]. Additionally, the implementation of various learning models has an impact on the increase in students' critical thinking ability $[38,40]$. In science learning, critical thinking ability has mainly been studied in school as well as college levels [41,42]. None of those studies, however, is related to Cirsa model implementation that impacts students' critical thinking ability in human excretion and respiratory systems contents. Therefore, the current research aims to know the influence of Cirsa learning model on critical thinking skills on human excretion and respiratory systems.

\section{Methods}

The research was a quasi-experiment using pretest-posttest non-equivalent control group design. The independent variables included learning models that consisted of CIRC, Cirsa, and conventional learning. Conventional learning is a learning design commonly implemented [43]. Thus it was used as a control in the research. The dependent variable was critical thinking skills on human excretion and respiratory systems. The research design is presented in Table 1 .

Table 1. Research Design of the Randomized Pretest- Posttest Control

\begin{tabular}{|c|c|c|}
\hline Group & & \\
\hline Pretest & Treatment & Posttest \\
\hline$T_{1}$ & $X_{1}$ & $\mathrm{~T}_{2}$ \\
\hline$T_{3}$ & $\mathrm{X}_{2}$ & $\mathrm{~T}_{4}$ \\
\hline $\mathrm{T}_{5}$ & $\mathrm{X}_{3}$ & $\mathrm{~T}_{6}$ \\
\hline
\end{tabular}

Note: T1,3 = Pretest; T2,4= Posttest; X1 = CIRSA learning; $\mathrm{X} 2=\mathrm{CIRC}$ learning; $\mathrm{X} 3=$ Conventional learning
The research population were all eight grade students at a Madrasah (junior high school) in Bogor Regency. Samples included 160 students taught on human excretion and respiratory systems. The sample was determined using random sampling technique preceded by the equality test of 10 classes. Random sampling was conducted by randomly selecting three classes. Each class received a similar learning opportunity yet different treatment based on the developed learning design. Each research group represented one class, which was class using CIRC, Cirsa, and conventional learning model.

Instruments used in the research had been stated as valid and reliable in terms of construct, content, and empirical according to Ratumanan [29]. The independent variable instruments consisted of syllabus, lesson plan, and students' worksheet developed, referring to the learning syntax of CIRC, Cirsa, and conventional worksheets. The learning was observed using learning implementation sheet. The dependent variable instruments were in the form of essay test questions on critical thinking skills on human excretion and respiratory systems. The questions of Biology-Critical thinking were developed adapted from Ennis [37], and also referring to the basic competences in the 2013 Curriculum. The learning objectives are presented in Table 2 . In its implementation, the learners were given a set of critical thinking skill questions on human excretion and respiratory systems to be solved independently for 50 minutes.

Table 2. Learning objectives of human excretion system and respiratory system

\begin{tabular}{|c|c|}
\hline Biology content concept & Learning indicators \\
\hline \multirow[t]{4}{*}{ Excretion system } & $\begin{array}{l}\text { Analyze organs contained in the human } \\
\text { excretion system }\end{array}$ \\
\hline & $\begin{array}{l}\text { Analyze the excretion system structure } \\
\text { and functions }\end{array}$ \\
\hline & $\begin{array}{c}\text { Evaluate disruptions occurred in the } \\
\text { excretion system }\end{array}$ \\
\hline & $\begin{array}{c}\text { Develop ideas in maintaining the health } \\
\text { of the excretion system }\end{array}$ \\
\hline \multirow[t]{4}{*}{ Respiratory system } & Analyze the respiratory system organs \\
\hline & Analyze respiration mechanism \\
\hline & $\begin{array}{c}\text { Evaluate disruptions in the respiratory } \\
\text { system }\end{array}$ \\
\hline & $\begin{array}{l}\text { Provide arguments on maintaining the } \\
\text { respiratory system health }\end{array}$ \\
\hline
\end{tabular}

The research data obtained were analyzed using descriptive statistics of average scores, deviation standard, and minimum and maximum values in each class. Hypothesis prerequisite tests included the normality test in the form of one-sample Kolmogorov-Smirnov test and homogeneity test using Levene's Test of Equality of Error Variance. The hypothesis testing was done using Ancova technique. All the data analysis techniques were conducted using statistical analysis application of SPSS 24.0 for Mac using significance level of $0.5 \%$. 


\section{Result and Discussion}

The research aimed to find out the influence of CIRC and Cirsa learning models on critical thinking skills on human excretion and respiratory systems. The descriptive data measurement results on pretest and posttest in the form of critical thinking skill scores are indicated in Table 3.

Table 3. Descriptive Data in Each Research Class

\begin{tabular}{|c|c|c|c|c|}
\hline \multirow{2}{*}{$\begin{array}{c}\text { Learning } \\
\text { Variable }\end{array}$} & \multicolumn{4}{|c|}{ Average and Category } \\
\cline { 2 - 5 } & Pretest & Category & Posttest & Category \\
\hline CIRSA Model & 57,38 & Less & 83,36 & Good \\
\hline CIRC Model & 53,01 & Less & 72,49 & Good \\
\hline $\begin{array}{c}\text { Conventional } \\
\text { Learning }\end{array}$ & 55,89 & Less & 69,66 & Less \\
\hline
\end{tabular}

Based on Table 3, it can be seen that after the learning process on human excretion and respiratory systems through Cirsa learning model, the critical thinking average was the highest compared to those through CIRC and conventional learning model. The Cirsa and CIRC learning models, according to the posttest scores, were learning models with good categories. The normality and homogeneity tests on the critical thinking skill data had been conducted before the hypothesis testing, and the results are described in Table 4.

Table 4. Summary of data analysis prerequisite test results

\begin{tabular}{|c|c|c|c|}
\hline Test & Sig. & $\alpha$ & Description \\
\hline Normality & 0.112 & 0.05 & Normal \\
\hline Homogeneity & 0.220 & 0.05 & Homogeneous \\
\hline
\end{tabular}

Based on Table 4, it can be inferred that critical thinking skill data had sig. values (level) in the normality and homogeneity tests that were greater than the alpha; thus, the data have not deviated from the normal distribution data, and the variance between the critical thinking data was not different or homogeneous.

Table 5. Ancova Test of the Influence of Learning Models on Critical Thinking

\begin{tabular}{|c|c|c|c|c|c|}
\hline Source & $\begin{array}{l}\text { type iii } \\
\text { sum of } \\
\text { squares }\end{array}$ & df & $\begin{array}{c}\text { mean } \\
\text { square }\end{array}$ & $\mathrm{f}$ & sig. \\
\hline $\begin{array}{c}\text { corrected } \\
\text { model }\end{array}$ & $12598.0^{\mathrm{a}}$ & 2 & 6299.0 & 111.8 & .000 \\
\hline intercept & 16048.2 & 1 & 16048.2 & 284.9 & .000 \\
\hline Pretest & 764.4 & 1 & 764.4 & 13.5 & .000 \\
\hline $\begin{array}{c}\text { learning } \\
\text { model }\end{array}$ & 11857.5 & 1 & 11857.5 & 210.5 & .000 \\
\hline Error & 8842.3 & 157 & 56.3 & & \\
\hline total & $\begin{array}{c}1015266 . \\
0\end{array}$ & 160 & & & \\
\hline $\begin{array}{c}\text { corrected } \\
\text { total }\end{array}$ & 21440.3 & 159 & & & \\
\hline
\end{tabular}

The ancova test was performed to proof the research hypothesis. The test, as indicated in Table 5, was resulted from sig. value $=0.000$, which was less than alpha of 0.05 . It could be inferred that there was an influence of learning models on critical thinking. The explanation is that the learning model applied in the excretion and respiratory systems learning on students of Madrasah influenced critical thinking skills. The post hoc test result (Table 6) shows that Biology learning through Cirsa was proven better than those through CIRC and conventional learning models. Critical thinking skill is related to one's cognitive development stage [44]. Madrasah students were at the formal operational level where an individual could think logically on abstract propositions and could formulate hypothesis and test them systematically.

Table 6. Summary of LSD Test Result on Critical Thinking

\begin{tabular}{|c|c|c|}
\hline \multirow{2}{*}{ (I) Learning Model } & (J) Learning Model & Sig. \\
\hline \multirow{2}{*}{ Cirsa } & CIRC & .000 \\
\cline { 2 - 3 } & Conventional & .000 \\
\hline \multirow{2}{*}{ CIRC } & Cirsa & .000 \\
\cline { 2 - 3 } & Conventional & .080 \\
\hline \multirow{2}{*}{ Conventional } & Cirsa & .000 \\
\cline { 2 - 3 } & CIRC & .080 \\
\hline
\end{tabular}

The research findings could be examined according to the applied learning model potentials. Critical thinking is related to a well-organized mental process. It plays a role in the decision-making process to solve problems by analyzing and interpreting data in scientific inquiry activities [45-47]. Those activities are part of a scientific approach. The conventional and CIRC learning models, however, have not accommodated activities that support those activities. Cirsa learning model, on the contrary, is CIRC learning model in the form of reading and writing activities integrated using scientific approach.

Based on one's skill related to critical thinking development and its association with cognitive development according to Piaget, Madrasah students should have entered the critical thinking skill development stage [44]. One effort to accelerate one's cognitive development is by involving and providing an environment suitable for the cognitive stage. This method could train learners to conduct investigation independently to solve problems, propose a solution, and compare their findings to others' $[13,48]$. The condition is following Cirsa learning model syntax that after the learners were given with assignments of analyzing contextual excretion and respiratory system contents and investigating the content from various sources where they had a responsibility to create a complete conclusion and problems occurred were written on the students' worksheet and presented during a discussion to be solved together.

Critical thinking ability intended in the research was a mental process consisting of ability to interpret, analyze, 
evaluate, conclude, communicate, and self-regulation. Thinking requires logical and analytical reasoning and indicates high-level critical thinking skills [49]. Further, theoretically and if related to Bloom's taxonomy, critical thinking skills that inherent to the high-level are analysis and synthesis. Technically, critical thinking comprises: understanding argumentation, recognizing false thinking, differentiating premise with the conclusion, separating issues with information $[18,50]$.

Familiarizing students to think critically should also be a conscious and planned effort $[23,25,26]$; thus, in the learning process of implementation, teachers bear responsibilities to integrate model to be used to critical thinking empowerment appropriately. Cirsa learning model contains study habituation that allows students' critical thinking empowerment by compiling questions, answering, and discussing answers through cooperative learning [8]. The cooperative-based activities are capable of training learners to ask and make questions; hence, critical thinking skills are well developed [33,34]. The link between Cirsa learning syntax and the critical thinking skill indicator is indicated in Table 7.

In the Cirsa learning model conducted cooperatively, learners are required to cooperate in a small group to discuss, analyze to understand and solve a variety of problems and encourage learners to communicate and exchange ideas; thus, it has potential for critical thinking ability empowerment. One of the essential elements in cooperative learning is the occurrence of social skill learning concerning leadership learning, decision making, building trust, communication, and handling problems together[31,32,51]. In cooperative work, providing learners with an opportunity to think with their peers and conduct discussion makes the thinking process becomes open to all learners. Training students to think critically through problem analysis method repeatedly helps students to master complex contents as well as empowers the critical thinking ability [52,53].

Biology learning through Cirsa is helpful for students to enhance critical thinking abilities. The use of Cirsa was suitable for Biology topics that require abilities to solve problems, such as topics on organ systems, genetics, ecosystem, and environment. In its implementation, Cirsa could be used in every face to face meeting or on a scheduled basis. The implementation of a model must consider students' characteristics [54-56]. It is related to a concern that if students who are taught using the Cirsa model have no sufficient basic ability, they will not be able to follow the learning. Hence, analysis is required as well as an observation of students' characteristics before the implementation of Cirsa in the classroom.

The effectiveness of Cirsa usage also depends on the number of students. In a class with a large number of students, such as $>50$ students in a classroom, it seems to be less effective since to train critical thinking ability demands discussion and question and answer process from every student. The Cirsa model would be difficult to implement in a large number of students since students will tend to be passive. Also, there is time limitation regarding discussion process where large number of students require a more extended time. Therefore, the Cirsa model should be implemented in a class with number of students in a range of 20-35 students. A small number of students results in better discussion, and students tend to be active in question and answer [57-59].

Table 7. Link between Cirsa learning syntax and critical thinking skills

\begin{tabular}{|c|c|c|c|}
\hline \multirow[t]{2}{*}{ CIRC Syntax } & \multicolumn{3}{|l|}{ Learning Activities } \\
\hline & Student Activities & $\begin{array}{l}\text { Scientific } \\
\text { Approach }\end{array}$ & $\begin{array}{l}\text { Critical } \\
\text { Thinking } \\
\text { Skills }\end{array}$ \\
\hline $\begin{array}{l}\text { Stage } 1 . \\
\text { Group division. }\end{array}$ & $\begin{array}{l}\text { 1. Listening to the explanation from the teacher and the steps of } \\
\text { learning. } \\
\text { 2. Formulating learning objectives. } \\
\text { 3. Link the excretion and respirarory system to be studied with the } \\
\text { previous concepts. } \\
\text { 4. Form heterogeneous groups ( } 4-5 \text { students). }\end{array}$ & Observe & Self-regulation \\
\hline $\begin{array}{l}\text { Stage } 2 . \\
\text { Reading } \\
\text { Discussion } \\
\text { fFinding the main concepts. }\end{array}$ & $\begin{array}{l}\text { 1. Exploring reading material or articles about the system of excretion } \\
\text { and breathing from various sources (internet and books). } \\
\text { 2. Reading, discussing with friends and understanding reading about } \\
\text { the system of excretion and respiratory. } \\
\text { 3. Finding facts, articles' main concept of the system of excretion and } \\
\text { respiratory, and re-write them on the students worksheet. }\end{array}$ & $\begin{array}{l}\text { Exploration } \\
\text { Exploration } \\
\text { Association, } \\
\text { Ask }\end{array}$ & $\begin{array}{l}\text { Analyzing, } \\
\text { Intepreting, } \\
\text { Concluding }\end{array}$ \\
\hline $\begin{array}{l}\text { Stage } 3 \\
\text { Group presentation. }\end{array}$ & $\begin{array}{l}\text { 1. Present the results of reading analysis and discussion about the } \\
\text { system of excretion and respiration, and continued with class } \\
\text { discussion. }\end{array}$ & Communicate & $\begin{array}{l}\text { Comunication, } \\
\text { Self-regulation }\end{array}$ \\
\hline
\end{tabular}

Note: Critical thinking indicators refers to Ennis [37], and learning activities adapted from Djamahar, et al., [7] 
Cirsa is an innovation in Biology learning. It can be implemented broadly at various levels, although the current research was limited to the secondary school level. Its usage is deemed suitable for primary school level since students' critical thinking skills begin to be trained at this level. It is related to changes in learning paradigms that lead more toward contextual matters. Moreover, the 21 st-century demand requires students to have high-level critical thinking ability. Thus, they could compete and adapt well with technology advancement [60-62]. At the college level, the Cirsa could also be applied since not all students have excellent critical thinking abilities. The Cirsa could be applied in, for example, college biology learning, such as in physiology, genetics and ecology courses.

The next step of the research was developing various Cirsa-based media. It aimed to integrate learning media with Cirsa model. A model that has integrated into Cirsa learning would facilitate teachers to apply both. As a consequence, teachers are no longer having difficulties in selecting suitable media to be applied to the Cirsa model. In addition to the development of Cirsa model-integrated media for students, a more general Cirsa-based media could be developed across disciplines. It, indeed, would require cooperation from various parties besides researchers and Biology teachers. Additionally, the use of Cirsa must be conducted consistently. It is due to the students' critical thinking ability enhancement that will grow if it is treated with a suitable learning model and is given consistently, and support with other learning media[40,63-67].

\section{Conclusions}

Based on the research findings, it can be inferred that the Cirsa learning model has proven to be more effective in enhancing critical thinking skills on human excretion and respiratory system. The influence of Cirsa learning on critical thinking skills was affected by the CIRC learning syntax that gave emphasize on group learning process to discuss and read contents related to human excretion and respiratory system based on scientific approach. The research results can be used as recommendations to empower critical thinking skills in Biology learning and support previous research findings [8]. Moreover, it is expected that Cirsa learning model could be implemented in a larger population and sample to strengthen the research findings. Also, further researches could consider analyzing the relationship between the mastery of biological concepts, metacognitive, and critical thinking skills after the implementation of Cirsa learning model.

\section{Acknowledgments}

The authors would like to thank all the students and teachers who have been participated in this research. This work was supported by Faculty of Mathematics and Natural Sciences, Universitas Negeri Jakarta, under grant number 40/PPK-FMIPA/BAP-PEN/V/2019.

\section{REFERENCES}

[1] Hernandez, A. M., Mañanas, M. A., \& Costa-Castelló, R. (2008). Learning respiratory system function in BME studies by means of a virtual laboratory: RespiLab. IEEE Transactions on Education, 51(1), 24-34. https://doi.org/10.1109/TE.2007.893355

[2] Durand, M. de T., Restini, C. B. A., Wolff, A. C. D., Faria M., Couto, L. B., \& Bestetti, R. B. (2019). Students' perception of animal or virtual laboratory in physiology practical classes in PBL medical hybrid curriculum. Advances in Physiology Education, 43(4), 451-457. https://doi.org/10.1152/advan.00005.2019

[3] Reinke, N. B. (2019). Promoting student engagement and academic achievement in first-year anatomy and physiology courses. Advances in Physiology Education, 43(4), 443-450. https://doi.org/10.1152/advan.00205.2018

[4] Quiroga, M. D. M., \& Choate, J. K. (2019). A virtual experiment improved students' understanding of physiological experimental processes ahead of a live inquiry-based practical class. Advances in Physiology Education, 43(4), 495-503. https://doi.org/10.1152/advan.00050.2019

[5] Blatch, S. A., Cliff, W., Beason-Abmayr, B., \& Halpin, P. A. (2017). The Fictional Animal Project: a Tool for Helping Students Integrate Body Systems. Advances in Physiology Education, 41(2), 239-243. https://doi.org/10.1152/advan.00159.2016

[6] Rao, S. P., \& DiCarlo, S. E. (2017). Active learning of respiratory physiology improves performance on respiratory physiology examinations. Advances in Physiology Education, 25(2), 55-61. https://doi.org/10.1152/advances.2001.25.2.55

[7] Djamahar, R., Ristanto, R. H., Sartono, N., Ichsan, I. Z., \& Muhlisin, A. (2018). CIRSA Designing Instructional Kits to Empower 21 st Century Skill. Educational Process: International Journal, 7(3), 200-208. https://doi.org/10.22521/edupij.2018.73.4

[8] Djamahar, R., Ristanto, R. H., Sartono, N., Ichsan, I. Z., Darmawan, E., \& Muhlisin, A. (2019). Empowering Student's Metacognitive Skill Through Cirsa Learning. In Journal of Physics: Conference Series (Vol. 1227, p. 12034). Malang. https://doi.org/10.1088/1742-6596/1227/1/012034

[9] Aydin, M. (2016). Exploring pre-service science teacher methods and strategies for the driving questions in research inquiry: From consulting an instructor to group discussion. International Journal of Environmental and Science Education, 11(5), 559-570. https://doi.org/10.12973/ijese.2016.404a

[10] Khasanah, A. N., Sajidan, S., \& Widoretno, S. (2017). Effectiveness of critical thinking indicator-based module in 
empowering student's learning outcome in respiratory system study material. Jurnal Pendidikan IPA Indonesia, 6(1), 187-195. https://doi.org/10.15294/jpii.v6i1.8490

[11] Gilissen, M. G. R., Knippels, M.-C. P. J., Verhoeff, R. P., \& van Joolingen, W. R. (2019). Teachers' and educators' perspectives on systems thinking and its implementation in Dutch biology education. Journal of Biological Education, $0(0)$,

https://doi.org/10.1080/00219266.2019.1609564

[12] Suwono, H., Pratiwi, H. E., Susanto, H., \& Susilo, H. (2017). Enhancement of students' biological literacy and critical thinking of biology through socio-biological case-based learning. Jurnal Pendidikan IPA Indonesia, 6(2), 213-222. https://doi.org/10.15294/jpii.v6i2.9622

[13] Ichsan, I. Z., Sigit, D. V., Miarsyah, M., Ali, A., Suwandi, T., \& Titin, T. (2020). Implementation supplementary book of green consumerism: improving students hots in environmental learning. European Journal of Educational Research, 9(1), 227-237. https://doi.org/10.12973/eu-jer.9.1.227

[14] Ichsan, I. Z., Sigit, D. V., Miarsyah, M., Ali, A., Arif, W. P., \& Prayitno, T. A. (2019). HOTS-AEP: Higher order thinking skills from elementary to master students in environmental learning. European Journal of Educational Research, 8(4), 935-942. https://doi.org/10.12973/eu-jer.8.4.935

[15] Paul, R., \& Elder, L. \& F. for C. T. (2009). The Miniature Guide to Critical Thinking-Concepts and Tools. Dillon Beach, CA: Foundation for Critical Thinking. https://doi.org/10.1002/pfi.4170340606

[16] Bustami, Y., Riyati, Y., \& Julung, H. (2019). Think talk write with pictured cards on human digestive system: impact of critical thinking skills. Biosfer: Jurnal Pendidikan Biologi, 12(1), 13-23

[17] Fitriani, H., Asy'ari, M., Zubaidah, S., \& Mahanal, S. (2019). Exploring the prospective teachers' critical thinking and critical analysis skills. Jurnal Pendidikan IPA Indonesia, 8(3), 379-390. https://doi.org/10.15294/jpii.v8i3.19434

[18] Muhlisin, A., Susilo, H., Amin, M., \& Rohman, F. (2016). Improving critical thinking skills of college students through RMS model for learning basic concepts in science. Asia-Pacific Forum on Science Learning and Teaching, 17(1), 1-24.

[19] Orozco, J. A., \& Yangco, R. T. (2016). Problem-based learning: effects on critical and creative thinking skills in biology. Asian Journal of Biology Education, 9, 1-10.

[20] Proulx, G. (2012). Integrating Scientific Method \& Critical Thinking in Classroom Debates on Environmental Issues. The American Biology Teacher, 66(1), 26-33. https://doi.org/10.2307/4451613

[21] Mahanal, S., Zubaidah, S., Sumiati, I. D., Sari, T. M., \& Ismirawati, N. (2019). RICOSRE: A Learning Model to Develop Critical Thinking Skills for Students with Different Academic Abilities. International Journal of Instruction, 12(2), 417-434 https://doi.org/10.29333/iji.2019.12227a

[22] Musyaddad, A., \& Suyanto, S. (2019). Evoking the four dimensions of student knowledge in ecosystem: effectiveness of real object, web, and blended learning. Biosfer: Jurnal Pendidikan Biologi, 12(2).

[23] Fuad, N. M., Zubaidah, S., Mahanal, S., \& Suarsini, E. (2017). Improving Junior High Schools' Critical Thinking Skills Based on Test Three Different Models of Learning. International Journal of Instruction, 10(1), 101-116. https://doi.org/10.12973/iji.2017.1017a

[24] Tsui, L. (2000). Effects of campus culture on students' critical thinking. The Review of Higher Education, 23(4), 421-441. https://doi.org/10.1353/rhe.2000.0020

[25] Miharja, F. J., Hindun, I., \& Fauzi, A. (2019). Critical thinking, metacognitive skills, and cognitive learning outcomes: A correlation study in genetic. Biosfer : Jurnal Pendidikan Biologi, 12(2), 135-143. https://doi.org/10.21009/biosferjpb.v12n2.135-143

[26] Bustami, Y., Syafruddin, D., \& Afriani, R. (2018). The implementation of contextual learning to enhance biology students' critical thinking skills. Jurnal Pendidikan IPA Indonesia, 7(4), 451-457. https://doi.org/10.15294/jpii.v7i4.11721

[27] Bruehl, M., Pan, D., \& Ferrer-Vinent, I. J. (2015). Demystifying the chemistry literature: Building information literacy in first-year chemistry students through student-centered learning and experiment design. Journal of Chemical Education. https://doi.org/10.1021/ed500412z

[28] Susiati, A., Adisyahputra, A., \& Miarsyah, M. (2018). Correlation of comprehension reading skill and higher-order thinking skill with scientific literacy skill of senior high school biology teacher. Biosfer: Jurnal Pendidikan Biologi, 11(1), 1-12.

[29] Ratumanan, T. ., \& Laurens, T. (2006). Evaluasi hasil belajar yang relevan dengan kurikulum berbasis kompetensi. Surabaya: Unesa University Press.

[30] Saputra, M. D., Joyoatmojo, S., Wardani, D. K., \& Sangka, K. B. (2018). Developing critical-thinking skills through the collaboration of jigsaw model with problem-based learning model. International Journal of Instruction, 12(1), 1077-1094. https://doi.org/10.29333/iji.2019.12169a

[31] Ristanto, R. H., Zubaidah, S., Amin, M., \& Rohman, F. (2018b). The Potential of Cooperative Integrated Reading and Composition in Biology Learning at Higher Education. International Journal of Educational Research Review, 3(1), $50-56$.

[32] Ristanto, R. H., Zubaidah, S., Amin, M., \& Rohman, F. (2018a). From a reader to a scientist: developing cirgi learning to empower scientific literacy and mastery of biology concept. Biosfer: Jurnal Pendidikan Biologi, 11(2), 90-100.

[33] Loes, C. N., \& Pascarella, E. T. (2017). Collaborative Learning and Critical Thinking: Testing the Link. The Journal of Higher Education, 88(5), 726-753. https://doi.org/10.1080/00221546.2017.1291257

[34] Yuriza, P. E., Adisyahputra, A., \& Sigit, D. V. (2018) Correlation between higher-order thinking skills and level of intelligence with scientific literacy on junior high school students. Biosfer, 11(1), 13-21.

[35] Liu, E. Z. F. (2007). Developing a personal and group-based 
learning portfolio system. British Journal of Educational Technology, 38(6), 1117-1121. https://doi.org/10.1111/j.1467-8535.2006.00691.x

[36] Ekawati, R., Susetyarini, E., Pantiwati, Y., \& Husamah, H. (2015). Peningkatan hasil belajar dan kemampuan berpikir kritis dengan model pembelajaran cooperative integrated reading and composition (CIRC). Jurnal Pendidikan Biologi Indonesia, 1(3), 298-306.

[37] Ennis, R. H. (2018). Critical Thinking Across the Curriculum: A Vision. Topoi, 37(1), 165-184. https://doi.org/10.1007/s11245-016-9401-4

[38] Saputri, A. C., Sajidan, S., Rinanto, Y., Afandi, A., \& Prasetyanti, N. M. (2018). Improving Students' Critical Thinking Skills in Cell-Metabolism Learning Using Stimulating Higher Order Thinking Skills Model. International Journal of Instruction, 12(1), 327-342. https://doi.org/10.29333/iji.2019.12122a

[39] Taft, M. M. (2015). Higher - Order Critical Thinking in Teacher Preparation. In Transformative Researchers and Educators for Democracy (pp. 57-73).

[40] Grant, M., \& Smith, M. (2018). Quantifying Assessment of Undergraduate Critical Thinking. Journal of College Teaching \& Learning, 15(1), 27-38.

[41] Roderer, T., \& Roebers, C. M. (2014). Can you see me thinking (about my answers)? Using eye-tracking to illuminate developmental differences in monitoring and control skills and their relation to performance. Metacognition and Learning, 9(1), 1-23. https://doi.org/10.1007/s11409-013-9109-4

[42] Song, X. (2016). "Critical Thinking" and Pedagogical Implications for Higher Education. East Asia, 33(1), 25-40. https://doi.org/10.1007/s12140-015-9250-6

[43] Ristanto, R. H., Zubaidah, S., Amin, M., \& Rohman, F. (2017). Scientific Literacy of Students Learned Through Guided Inquiry. International Journal of Research \& Review, 234(5), 23-30.

[44] Darmawan, E., Zubaidah, S., Susilo, H., \& Suwono, H. (2016). Simas eric Model to Improve Students' Critical Thinking Skills Faculty of Mathematics and Science. Journal of Education \& Social Policy, 3(6), 45-53.

[45] Wang, A., Liyanage, I., \& Walker, T. (2019). Scrutinising Critical Thinking (CT) in Chinese Higher Education: Perceptions of Chinese Academics (pp. 189-208). Springer, Cham. https://doi.org/10.1007/978-3-030-14386-2_11

[46] Demir, M., Bacanli, H., Tarhan, S., \& Ali Dombayci, M. (2011). Quadruple thinking: Critical thinking. In Procedia Social and Behavioral Sciences. https://doi.org/10.1016/j.sbspro.2011.02.066

[47] Mccutcheon, K., Lohan, M., Traynor, M., \& Martin, D. (2015). A systematic review evaluating the impact of online or blended learning vs. face-to-face learning of clinical skills in undergraduate nurse education. Journal of Advanced Nursing, 71(2), 255-270. https://doi.org/10.1111/jan.12509

[48] Ku, K. Y. L. \& Ho, I. T. (2010). Metacognitive strategies that enhance critical thinking. Metacognition and Learning. https://doi.org/10.1007/s11409-010-9060-6
[49] Darmawan, E., Brasilita, Y., Zubaidah, S., \& Saptasari, M. (2018). Meningkatkan Keterampilan Metakognitif Siswa Berbeda Gender dengan Model Pembelajaran Simas Eric di SMAN 6 Malang. Biosfer: Jurnal Pendidikan Biologi, 11(1), 47-56.

[50] Aizikovitsh-Udi, E., \& Amit, M. (2011). Developing the skills of critical and creative thinking by probability teaching. Procedia - Social and Behavioral Sciences, 15, 1087-1091. https://doi.org/10.1016/j.sbspro.2011.03.243

[51] Lestari, P., Ristanto, R., \& Miarsyah, M. (2019). Analysis of Conceptual Understanding of Botany and Metacognitive Skill in Pre-Service Biology Teacher in Jakarta, Indonesia. Journal for the Education of Gifted Young Scientists, 7(2), 199-214. https://doi.org/10.17478/jegys.515978

[52] Jackson, M. C. (2001). Critical systems thinking and practice. European Journal of Operational Research. https://doi.org/10.1016/S0377-2217(00)00067-9

[53] Saadé, R. G., Morin, D., \& Thomas, J. D. E. (2012). Critical thinking in E-learning environments. Computers in Human Behavior. https://doi.org/10.1016/j.chb.2012.03.025

[54] Anagün, S. S. (2018). Teachers' Perceptions about the Relationship between 21st Century Skills and Managing Constructivist Learning Environments. International Journal of Instruction, 11(4), 825-840. https://doi.org/10.12973/iji.2018.11452a

[55] Lince, R. (2016). Creative Thinking Ability to Increase Student Mathematical of Junior High School by Applying Models Numbered Heads Together. Journal of Education and Practice, 7(6), 206-212.

[56] Vidergor, H. E. (2018). Effectiveness of the multidimensional curriculum model in developing higher-order thinking skills in elementary and secondary students. Curriculum Journal, 29(1), 95-115. https://doi.org/10.1080/09585176.2017.1318771

[57] Derevenskaia, O. (2014). Active Learning Methods in Environmental Education of Students. Procedia - Social and Behavioral Sciences, 131, 101-104 https://doi.org/10.1016/j.sbspro.2014.04.086

[58] Stover, S., \& Ziswiler, K. (2017). Impact of Active Learning Environments on Community of Inquiry. International Journal of Teaching and Learning in Higher Education, 29(3), 458-470.

[59] Tesfaye, S., \& Berhanu, K. (2015). Improving Students Participation in Active Learning Methods: Group Discussions, Presentations and Demonstrations: A Case of Madda Walabu University Second Year Tourism Management Students of 2014. Journal of Education and Practice, 6(22), 29-33.

[60] Aslan, S. (2015). Is learning by teaching effective in gaining 21st century skills? The views of pre-service science teachers. Kuram ve Uygulamada Egitim Bilimleri, 15(6), 1441-1457. https://doi.org/10.12738/estp.2016.1.0019

[61] Evans, C. (2014). Twitter for teaching: Can social media be used to enhance the process of learning? British Journal of Educational Technology, 45(5), 902-915. https://doi.org/10.1111/bjet.12099

[62] Lay, A. N., \& Osman, K. (2018). Developing 21st Century 
Chemistry Learning through Designing Digital Games. Journal of Education in Science, Environment and Health, 4(1), 81-92. https://doi.org/10.21891/jeseh.387499

[63] Motallebzadeh, K., Ahmadi, F., \& Hosseinnia, M. (2018). Relationship between 21 st century skills, speaking and writing skills: A structural equation modelling approach. International Journal of Instruction, 11(3), 265-276. https://doi.org/10.12973/iji.2018.11319a

[64] Wang, S., \& Wang, H. (2011). Teaching Higher Order Thinking in the Introductory MIS Course: A Model-Directed Approach. Journal of Education for Business, 86(4),

https://doi.org/10.1080/08832323.2010.505254

[65] Ristanto, R.H,. Miarsyah, M., Muharomah, D.R., Astuti, T.A., Aini, S., \& Prihatin., A.I (2019). Light-Board: simple media to learn photosynthesis concepts. International Journal of Advanced Trends in Computer Science and Engineering,

299-303.https://doi.org/10.30534/ijatcse/2020/45912020

[66] Supriyatin, Rahayu, S., Ristanto, R.H., Ichsan, I.Z. (2019). Improving hots in biology learning: A supplement book of plant growth and development. Universal Journal of Educational Research, 7(12), 2642-2646

[67] Miarsyah, M., Ristanto, R.H., Nurhayati, Mufida, S.N., Suparini, Zharroh, A.E. (2020). Development of adobe flash media integrated into hots on circulation system (af-hots bicycle media). International Journal of Advanced Trends in Computer Science and Engineering, 9(1), 896-903. https://doi.org/10.30534/ijatcse/2020/128912020 